\title{
AKTIVITAS ANTIOKSIDAN KITOSAN PADA OVARIUM TIKUS BETINA YANG TERPAPAR TIMBAL (Pb) ASETAT
}

\author{
Asri Iman Sari ${ }^{1}$, Sri Nengsi Destriani ${ }^{1}$, Setyawati Soeharto ${ }^{2}$, Bambang Raharjo ${ }^{3}$ \\ Sutrisno $^{3}$, Karyono Mintaroem ${ }^{4}$ \\ ${ }^{1}$ Program Studi Magister Kebidanan Fakultas Kedokteran Universitas Brawijaya \\ ${ }^{2}$ Departemen Farmakologi Fakultas Kedokteran Universitas Brawijaya \\ ${ }^{3}$ Divisi Obstetri Ginekologi RSUD Saiful Anwar, Fakultas Kedokteran Universitas Brawijaya \\ ${ }^{4}$ Departement Patologi Anatomi Fakultas Kedokteran Universitas Brawijaya
}

Email: asriimansari.286@gmail.com

\section{(Chitosan As Antioxidants Agent In Female Rat Ovary Exposed Lead Acetate)}

\begin{abstract}
ABSTRAK
Penelitian ini bertujuan untuk mengetahui pengaruh kitosan terhadap ekspresi Bax dan jumlah atresia folikel pada ovarium tikus betina yang terpapar timbal asetat. Penentuan sampel dilakukan secara random, 25 ekor tikus betina sesuai kriteria inklusi dan ekslusi dibagi menjadi 5 kelompok. Semua kelompok, kecuali kelompok kontrol negatif diberi timbal asetat $175 \mathrm{mg} / \mathrm{kg}$ BB. Kelompok perlakuan 1, 2, dan 3 diberi kitosan yang dilarutkan dalam asam asetat $2 \%$ dengan dosis 16,32 , dan $64 \mathrm{mg} / \mathrm{kg}$ BB. Pemberian timbal asetat dan kitosan melalui sonde per oral. Aklimatisasai dilakukan selama 7 hari dan perlakuan selama 30 hari. Hari ke 31 dilakukan swab vagina. Jika tikus pada fase proestrus maka tikus dibedah dan diambil ovariumnya. Pengukuran ekspresi Bax menggunakan metode imunohistokimia dan penghitungan jumlah folikel atresia menggunakan metode hematoksilin eosin yang dilihat dengan mikroskop Olympus pembesaran 400x. Hasil penelitian menunjukkan bahwa kelompok perlakuan yang diberi timbal asetat dan kitosan berbagai dosis memiliki ekspresi Bax dan jumlah atresia folikel yang berbeda signifikan dengan kelompok kontrol negatif.
\end{abstract}

Kata kunci: kitosan, antioksidan, timbal asetat

\section{ABSTRACT}

This research aims the effect of chitosan on bax expression and the number of follicle atresia in the ovary of female rat exposed lead acetate. Twenty five rats were divided into 5 treatment groups. All groups, except negative control group, were administered by $175 \mathrm{mg} / \mathrm{kg}$ $B W$ oral lead acetate. Treatment group 1,2, and 3 were treated using chitosan in dose of 16, 32 , and $64 \mathrm{mg} / \mathrm{kg} \mathrm{BW}$ dissolved in 2\% acetic acid, respectively in 30 days. Before treated rat need acclimatization in 7 days. Administration of lead acetate and chitosan via sonde orally. Vaginal swabs in day 31, if rat in proestrus phase dissected and taken the ovary. Bax expression calculation with immunohistochemistry method and the number of follicle atresia calculation with hematoksilin eosin method. And then viewed use Olympus microscope zoom in 400. Results showed that Chitosan-treated groups in bax expression ang the number of follicle atresia differ significantly with negative control group.

Keywords: chitosan, antioxidant, lead acetate 


\section{PENDAHULUAN}

Perkembangan teknologi dan industri saat ini mempunyai dampak negatif pada lingkungan terutama yang mengandung zat berbahaya seperti logam berat salah satunya adalah timbal. Timbal sangat berbahaya bila terhirup dan terkonsumsi yang berasal dari makanan. Timbal yang membahayakan kesehatan dapat berbentuk timbal karbonat (timbal putih), timbal tetraoksida (timbal merah), timbal monoksida, timbal sulfida, timbal asetat (bentuk timbal yang sering menyebabkan keracunan). Timbal yang masuk dalam tubuh akan diabsorbsi melalui saluran pernafasan 5-30\%, saluran pencernaan 5-10\%, dan kontak dermal (Suksmerri, 2008 ; Sundari et al., 2016).

Paparan timbal secara terus menerus akan terakumulasi dalam tubuh hingga menyebabkan toksisitas dan berpotensi mempengaruhi sistem reproduksi yang dapat mengakibatkan infertilitas, cacat bawaan pada janin, serta abortus spontan. Sebuah studi pada pekerja wanita di pabrik peleburan timbal di Swedia terjadi 13,9\% abortus spontan saat bekerja selama kehamilannya dan $17 \%$ kejadian abortus spontan terjadi pada pekerja yang bekerja di pabrik peleburan sebelum kehamilan dan bertempat tinggal $10 \mathrm{~km}$ dari pabrik peleburan timbal. Timbal dapat melintasi membran dan terakumulasi dalam jaringan lunak seperti ovarium (Gupta, 2013). Hal ini memungkinkan juga terjadi pada folikel ovarium menjadi atresia.

Paparan timbal dapat meningkatkan produksi radikal bebas hingga menyebabkan stres oksidatif yang ditandai dengan penurunan antioksidan dalam tubuh. Molekul radikal bebas dan senyawa turunannya, reactive oxygen species (ROS) dapat menyerang sel sehingga menimbulkan berbagai kerusakan pada sel yang tidak dapat diperbaiki lagi yang disebut apoptosis. Apoptosis melibatkan keseimbangan protein anti dan pro apoptosis yaitu Bcl-2 dan Bax. Upaya untuk mengatasi terjadinya apoptosis yang tidak diinginkan akibat ROS yang berlebih dalam tubuh dapat dicegah dengan pemberian antioksidan, salah satunya kitosan. Kitosan merupakan turunan dari kitin yang didapatkan dari ekstrak kulit krustasea. Gugus amino $\left(\mathrm{NH}_{2}\right)$ dan gugus hidroksil $(\mathrm{OH})$ di dalam kitosan merupakan kunci gugus fungsional dari aktifitas antioksidan pada kitosan (Aprilia, 2015). Penelitian ini bertujuan untuk mengetahui pengaruh kitosan terhadap ekspresi Bax dan jumlah atresia folikel pada ovarium tikus betina yang terpapar timbal asetat.

\section{METODE}

Penelitian ini dilakukan secara true experiment laboratory dengan post test only with control group design. Penelitian dilakukan di Laboratorium Farmakologi untuk pemeliharaan hewan coba dan untuk memeriksa ekspresi Bax dan penghitungan jumlah folikel atresia di laboratorium patologi anatomi.

Dua puluh lima tikus yang memenuhi kriteria inklusi dipilih untuk dilakukan perlakuan. Kriteria inklusi yaitu tikus (Rattus norvegicus) Galur Wistar berjenis kelamin betina ( $(+)$ yang sehat (aktif, bulu berwarna putih bersih, tidak ada cacat, tidak hamil), tidak pernah digunakan sebagai hewan coba sebelumnya, usia 9-12 minggu, berat badan antara 150-200 gram. Lalu tikus dipilih secara random dan dikelompokan menjadi 5 sehingga tiap kelompok berisi 5 ekor tikus (rumus replikasi Federer). Kelompok 1 adalah kontrol negatif, kelompok 2 adalah kontrol positif yang diberi timbal asetat $175 \mathrm{mg} / \mathrm{kg} \mathrm{BB}$, kelompok 3 adalah perlakuan 1 yang diberi timbal asetat $175 \mathrm{mg} / \mathrm{kg} \mathrm{BB}$ dan kitosan 16 $\mathrm{mg} / \mathrm{kg} \mathrm{BB}$, kelompok 4 adalah perlakuan 2 yang diberi timbal asetat $175 \mathrm{mg} / \mathrm{kg} \mathrm{BB}$ dan kitosan $32 \mathrm{mg} / \mathrm{kg} \mathrm{BB}$, dan kelompok 5 yang diberi timbal asetat $175 \mathrm{mg} / \mathrm{kg}$ BB dan kitosan $64 \mathrm{mg} / \mathrm{kg}$ BB. Timbal dilarutkan dengan air sedangkan kitosan dilarutkan dalam asam asetat 2\%. Makan dan minum tikus diberikan secara ad libitum.

Aklimatisasi dilakukan selama 7 hari dan perlakuan dilakukan selama 30 hari. Setelah itu dilakukan swab vagina, bila tikus pada fase proestrus maka dilakukan pembedahan untuk diambil ovariumnya. Selanjutnya 
dibuat preparat histopatologi untuk pemeriksaan imunohistokimia dan hematoksilin eosin dan dibaca di mikroskop olympus dengan pembesaran 400x.

Data dianalisis menggunakan uji one way ANOVA dengan bantuan SPSS. Bila hasil didapatkan ada perbedaan dilanjutkan dengan analisis menggunakan LSD (Least Significant Difference).

\section{HASIL}

\section{Ekspresi Bax Sel Granulosa Folikel Antral}

Hasil perhitungan ekspresi bax sel granulosa folikel antral ditunjukan pada Gambar 1.

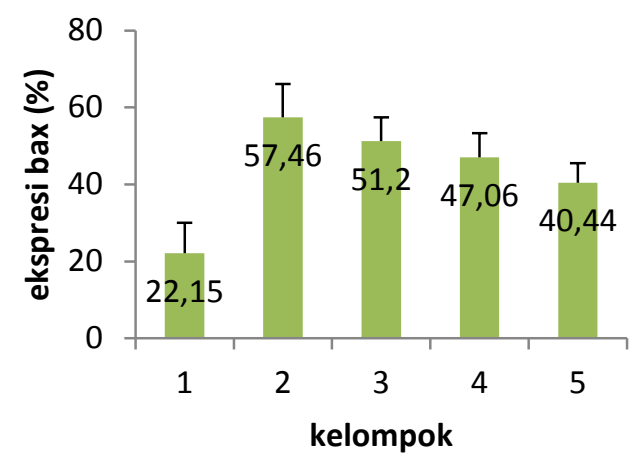

Keterangan : 1) kontrol negatif; 2) kontrol positif (timbal asetat $175 \mathrm{mg} / \mathrm{kg} \mathrm{BB}$ ); 3) perlakuan 1 (timbal asetat $175 \mathrm{mg} / \mathrm{kg} \mathrm{BB}+\mathrm{kitosan} 16 \mathrm{mg} / \mathrm{kg}$ $\mathrm{BB}$ ); 4) perlakuan 2 (timbal asetat $175 \mathrm{mg} / \mathrm{kg}$ $\mathrm{BB}+$ kitosan $32 \mathrm{mg} / \mathrm{kg} \mathrm{BB}$ ); 5) perlakuan 3 (timbal asetat $175 \mathrm{mg} / \mathrm{kg} \mathrm{BB}+\mathrm{kitosan} 64 \mathrm{mg} / \mathrm{kg}$ BB).

Gambar 1. Perbedaan Ekspresi Bax Sel Granulosa Folikel Antral Pada Tikus Yang Diberi Timbal Asetat Dan Kitosan Berbagai Dosis

Hasil uji prasyarat parametrik menggunakan uji asumsi normalitas dan homogenitas menunjukkan bahwa ekspresi bax sel granulosa folikel antral terdistribusi normal dan homogen. Oleh karena itu uji one way ANOVA dapat digunakan. Hasilnya didapatkan perbedaan antar kelompok dengan $p$-value 0,000 lebih kecil dari $\alpha 0,05$ ( $p$-value < 0,05). Lalu dilanjutkan dengan analisis LSD. Hasil perhitungan LSD terdapat pada tabel 1 .
Tabel 1. Hasil Analisis LSD Ekspresi Bax Sel Granulosa Folikel Antral Pada Tikus Yang Diberi Timbal Asetat Dan Kitosan Berbagai Dosis

\begin{tabular}{ll}
\hline Kelompok & Rerata* $^{*}$ \\
\hline Kontrol negatif & $22,15^{\mathrm{a}}$ \\
Perlakuan 3 & $40,44^{\mathrm{b}}$ \\
Perlakuan 2 & $47,06^{\mathrm{bc}}$ \\
Perlakuan 1 & $51,2^{\mathrm{bc}}$ \\
Kontrol positif & $57,46^{\mathrm{c}}$ \\
\hline
\end{tabular}

*Perbedaan huruf menunjukkan perbedaan yang signifikan $(\mathrm{p}<0,05)$

Hasil analisis LSD menunjukkan bahwa semua kelompok terdapat perbedaan yang signifikan terhadap kontrol negatif. Hal ini menunjukkan bahwa kitosan memiliki aktivitas antioksidan pada tikus yang diberi timbal asetat.

Pada kelompok kontrol positif memiliki nilai rerata paling tinggi dibandingkan dengan kelompok kontrol negatif dan perlakuan kitosan berbagai dosis karena pada kelompok kontrol positif hanya diberi timbal asetat tanpa mendapatkan kitosan sehingga sel granulosa folikel antral lebih banyak yang mengekspresikan bax karena pengaruh timbal asetat yang diberikan per oral. Jumlah ekspresi bax sel granulosa folikel antral pada kelompok perlakuan kitosan berbagai dosis mengalami penurunan sesuai dengan dosis kitosan yang diberikan.

\section{Jumlah Atresia Folikel Antral}

Hasil perhitungan jumlah folikel atresia ditunjukkan Gambar 2. 


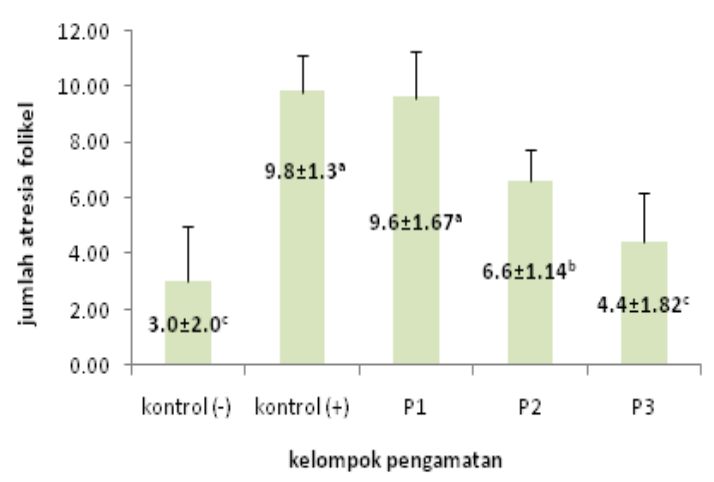

Keterangan: 1) kontrol negatif; 2) kontrol positif (timbal asetat $175 \mathrm{mg} / \mathrm{kg} \mathrm{BB}$ ); 3) perlakuan 1 (timbal asetat $175 \mathrm{mg} / \mathrm{kg} \mathrm{BB}+\mathrm{kitosan} 16 \mathrm{mg} / \mathrm{kg}$ $\mathrm{BB}$ ); 4) perlakuan 2 (timbal asetat $175 \mathrm{mg} / \mathrm{kg}$ BB+kitosan $32 \mathrm{mg} / \mathrm{kg} \mathrm{BB}$ ); 5) perlakuan 3 (timbal asetat $175 \mathrm{mg} / \mathrm{kg} \mathrm{BB}+\mathrm{kitosan} 64 \mathrm{mg} / \mathrm{kg}$ BB).

Gambar 2. Perbedaan Jumlah Folikel Atresia Pada Tikus Yang terpapar Timbal Asetat diberi Dan Tidak Diberi Kitosan Dengan Berbagai Dosis.

Hasil uji prasyarat parametrik menggunakan uji asumsi normalitas dan homogenitas menunjukkan bahwa jumlah atresia folikel terdistribusi normal dan homogen. Oleh karena itu uji one way ANOVA dapat digunakan. Hasilnya didapatkan perbedaan antar kelompok dengan $p$-value 0,000 lebih kecil dari $\alpha 0,05$ ( $p$-value < 0,05$)$. Lalu dilanjutkan dengan analisis LSD. Hasil perhitungan LSD terdapat pada Tabel 2 .

Tabel 2. Hasil Analisis LSD Jumlah Folikel Atresia Pada Tikus Yang Diberi Timbal Asetat Dan Kitosan Berbagai Dosis

\begin{tabular}{cccc}
\hline $\begin{array}{c}\text { Kelompok } \\
\text { pengamatan }\end{array}$ & $\mathrm{n}$ & Rerata $\pm \mathrm{SD}$ & p-value \\
\hline kontrol & 5 & $9.8 \pm 1.3^{\mathrm{a}}$ & \\
positif & & & \\
P1 & 5 & $9.6 \pm 1.67^{\mathrm{a}}$ & $0.000<\propto$ \\
P2 & 5 & $6.6 \pm 1.14^{\mathrm{b}}$ & \\
P3 & 5 & $4.4 \pm 1.82^{\mathrm{c}}$ & \\
\hline
\end{tabular}

Keterangan : Pada rerata \pm SD menunjukkan hasil uji LSD jika memuat huruf yang berbeda berarti ada perbedaan yang bermakna ( $p$-value < $0.05)$ dan jika memuat huruf yang sama berarti tidak ada perbedaan yang bermakna ( $p$-value > $0.05)$.

\section{PEMBAHASAN \\ Ekspresi Bax}

Bax merupakan protein Bcl-2 family yang berperan sebagai protein pro apoptosis melalui jalur intrinsik. Apoptosis jalur intrinsik merupakan kematian sel yang terprogram dan melibatkan protein apoptosis seperti Bcl-2 sebagai protein anti apoptosis dan Bax sebagai protein pro apoptosis. Apoptosis akan terjadi jika protein pro apoptosis lebih banyak daripada protein anti apoptosis (Merino et al, 2014). Menurut Hussein (2005) secara morfologi, apoptosis pada folikel ovarium akan terjadi pada masa fetus dan dewasa. Dalam hal ini sel granulosa yang mengekspresikan Bax adalah sel granulosa folikel antral.

Peningkatan ekspresi Bax sebagai protein pro apoptosis didasarkan pada mekanisme kerja timbal. Mekanisme kerja timbal dapat melalui peningkatan ROS. Timbal dalam darah dapat menghambat kompleks enzim sulfhidril sehingga menginaktivasi kerja glutathione. Glutathione yang merupakan sistem pertahanan tubuh untuk melawan radikal bebas. Paparan timbal secara terus menerus dalam waktu lama dapat membuat ketidakseimbangan antioksidan dan ROS dalam tubuh sehingga terjadi stres oksidatif. Stres oksidatif dalam tubuh mengakibatkan kerusakan DNA sehingga memicu terjadinya apoptosis melalui jalur intrinsik. Apoptosis jalur intrinsik terjadi karena adanya sinyal dalam sel yang melibatkan protein Bcl-2 family seperti Bax dan Bcl-2 (Agarwal et al, 2012; Flora et al, 2012; Osthoff, 2008).

\section{Jumlah Atresia Folikel Antral}

Tampak pada hasil uji perbandingan yang ditunjukkan di Tabel 2 di atas bahwa tidak ada perbedaan yang bermakna rerata jumlah atresia folikel antara kelompok positif (tikus dengan paparan timbal asetat) $\left(9.8 \pm 1.3^{\mathrm{a}}\right)$ dengan kelompok P1 atau kelompok perlakuan paparan timbal asetat + kitosan dosis $16 \mathrm{mg} / \mathrm{KgBB} /$ hari $\left(9.6 \pm 1.67^{\mathrm{a}}\right)$. Tampak nilai rerata jumlah atresia folikel kelompok kontrol positif lebih besar bila dibandingkan dengan rerata jumlah atresia folikel pada kelompok P1. Hal ini berarti bahwa jumlah 
atresia folikel pada ovarium akan sedikit menurun pada tikus yang diberi perlakuan paparan timbal asetat+ kitosan 16 $\mathrm{mg} / \mathrm{KgBB} /$ hari bila dibandingkan dengan tikus yang terpapar timbal asetat, meskipun penurunan ini tidak bermakna secara statistik. Dengan kata lain paparan timbal asetat + kitosan $16 \mathrm{mg} / \mathrm{KgBB} / \mathrm{hari}$ pada tikus Rattus norvegicus dapat dikatakan belum cukup mampu menurunkan jumlah atresia folikel pada ovarium.

Akan tetapi tidak demikian antara kelompok kontrol positif (tikus dengan paparan timbal asetat) $\left(9.8 \pm 1.3^{\mathrm{a}}\right)$ dengan kelompok P2 atau kelompok perlakuan paparan timbal asetat + kitosan dosis 32 $\mathrm{mg} / \mathrm{KgBB} /$ hari $\quad\left(6.6 \pm 1.14^{\mathrm{b}}\right)$ menunjukkan bahwa ada perbedaan yang bermakna rerata jumlah atresia folikel. Pada nilai rerata jumlah atresia folikel kelompok kontrol positif menunjukkan nilai yang lebih besar bila dibandingkan dengan rerata jumlah atresia folikel pada kelompok P2. Hal ini berarti bahwa tikus dengan paparan timbal asetat + kitosan 32mg/KgBB/hari akan menurunkan jumlah atresia folikel pada ovarium bila dibandingkan dengan tikus yang terpapar timbal asetat. Dengan kata lain paparan timbal asetat+ kitosan $32 \mathrm{mg} / \mathrm{KgBB} / \mathrm{hari}$ pada tikus Rattus norvegicus dapat menurunkan jumlah atresia folikel pada ovarium.

Hasil di Tabel 2 menunjukkan pula bahwa ada perbedaan yang bermakna rerata jumlah atresia folikel antara kelompok kontrol positif (tikus dengan paparan timbal asetat) $\left(9.8 \pm 1.3^{\mathrm{a}}\right)$ dengan kelompok P3 atau kelompok perlakuan paparan timbal asetat + kitosan dosis $64 \mathrm{mg} / \mathrm{KgBB} / \mathrm{hari}$ (4.4 \pm $1.82^{\mathrm{c}}$ ). Nilai rerata jumlah atresia folikel kelompok kontrol positif lebih besar bila dibandingkan dengan rerata jumlah atresia folikel pada kelompok P3. Berarti bahwa tikus dengan perlakuan pemberian paparan timbal asetat + kitosan $64 \mathrm{mg} / \mathrm{KgBB} / \mathrm{hari}$ akan menurunkan jumlah atresia folikel pada ovarium bila dibandingkan dengan tikus yang terpapar timbal asetat. Dengan kata lain paparan timbal asetat + kitosan 64 $\mathrm{mg} / \mathrm{KgBB} /$ hari pada tikus Rattus norvegicus dapat menurunkan jumlah atresia folike pada ovarium.

Pada penjelasan hasil dari Tabel 2 di atas maka dapat diartikan bahwa perlakuan pemberian kitosan dosis $32 \mathrm{mg} / \mathrm{KgBB} /$ hari dan dosis $64 \mathrm{mg} / \mathrm{KgBB} /$ hari pada tikus Rattus norvegicus yang terpapar timbal asetat berpengaruh bermakna terhadap penurunan jumlah atresia folikel. Jadi hipotesis terbukti, yaitu adanya perbedaan jumlah atresia folikel pada ovarium tikus (Rattus norvegicus) betina Galur Wistar yang terpapar timbal asetat $(\mathrm{Pb})$ diberi dan tidak diberi kitosan.

Folikel antral merupakan kandidat marker yang kuat untuk menilai cadangan folikel di ovarium karena akan menentukan tingkat fertilitas pada wanita. Pemberian timbal asetat melalui oral akan diabsorpsi oleh tubuh melalui sistem pencernaan, didistribusikan ke seluruh tubuh lalu dimetabolisme dalam darah dan masuk dalam hipotalamus, ovarium, dan lain-lain (Hoyer, 2013; Nordberg, 2015). Timbal akan merusak hipotalamus dan fungsi kelenjar pituitari. Hipotalamus akan menghambat sekresi Gonadotropin Releasing Hormone (GnRH) sehingga akan berdampak pada disfungsi reproduksi (Evans, 2015; Gupta, 2011). Penurunan Follicle Stimulating Hormone (FSH) yang diproduksi kelenjar hipofisis akan terjadi akibat pengaruh produksi GnRH terhambat sehingga estradiol juga menurun. Penurunan kadar FSH akan menyebabkan folikel ovarium mengalami atresia (Dumitrescu et al, 2014).

Dalam keadaan fisiologis produksi radikal bebas (ROS) seimbang dengan antioksidan (SOD, CAT, GSH) dalam tubuh. Timbal dapat berikatan dengan kelompok sulfhidril pada SOD, CAT, dan glutathione sehingga menjadi tidak aktif. Adanya inaktifasi glutathione, SOD, dan CAT berdampak pada menurunnya antioksidan dalam tubuh dan ROS meningkat sehingga dapat memicu terjadinya stres oksidatif.

Pada penelitian ini untuk menetralisir stres oksidatif akibat pemberian timbal asetat, tikus diberi kitosan pada kelompok perlakuan dengan berbagai dosis. Kitosan 
dapat mengkelat timbal asetat yang diberikan. Selain itu kitosan memiliki gugus amino bebas $\mathrm{NH}_{2}$ yang dapat berikatan dengan $\mathrm{OH}^{-}$hasil dari proses oksidasi lipid sehingga membentuk molekul yang lebih stabil. Diduga hal tersebut yang dapat menyebabkan penurunan jumlah folikel atresia pada ovarium tikus (Rattus norvegicus) betina yang diberi timbal $(\mathrm{Pb})$ asetat per oral pada kelompok perlakuan berbagai dosis. Berdasarkan hasil penelitian dan kajian teori tersebut maka terbukti bahwa kitosan dapat mencegah peningkatan jumlah folikel atresia ovarium pada tikus (Rattus norvegicus) betina yang diberi timbal $(\mathrm{Pb})$ asetat per oral.

\section{PENUTUP}

Kitosan memiliki aktivitas antioksidan pada tikus yang terpapar timbal asetat. Untuk penelitian selanjutnya perlu pemeriksaan di organ reproduksi lainnya.

\section{REFERENSI}

Agarwal, A., Aponte-Mellado, A., Premkumar, B. J., Shaman, A., \& Gupta, S. (2012). The effects of oxidative stress on female reproduction: a review. reproductive biology and endocrinology.

Aprilia, D. (2015). Potensi Kitosan sebagai Agen Antioksidatif pada Hepar yang Diinduksi Plumbum. Majority, 4(8), 85-88.

Dumitrescu, E., Cristina, R. T., \& Muselin, F. (2014). Reproductive biology study of dynamics of female sexual hormones: a 12month exposure to lead acetate rat model. Turkish Journal of Biology, 38, 581-585.

Evans, T. J. (2015). Handbook of Toxicology of Chemical Warfare Agent (2 ed.).

Flora, G., Gupta, D., \& Tiwari, A. (2012). Toxicity of Lead: A review with recent updates. Interdiciplinary Toxicology, 5(2), 47-58.

Gupta, R. G. (2013). Reproductive and developmental Toxicology. American Journal of Pharmaceutical Education, 77(1).
Hoyer, P. B. (2013). Ovarian Toxicology (2 ed.). London: Taylor \& Francis Group.

Hussein, M. R. (2005). Apoptosis in the ovary: molecular mechanisms. HUman Reproduction Updates, 11(2), 162-178.

Lubis, B., Rosdiana, N., Nafianti, S., Rasyianti, O., \& Panjaitan, F. M. (2013). Hubungan Keracunan Timbal dengan Anemia Defisiensi Besi pada Anak. Cdk200, 40(1).

Marianti, A., Anatiasara, D., \& Ashar, F. F. (2017). Chitosan as Chelating and Protective Agents from Lead Intoxication in Rat. Biosaintifika, 9(1), 126-133.

Merino, J. M., Paredes, A. C., Ulloa, E. V., Zavaleta, L. R., Gonzalez, A. M. F., \& Lizano, M. (2014). The Role of Signaling Pathways in Cervical Cancer and Molecular Therapeutic Targets. Archives of Medical Research, 45, 525-539.

Nordberg, G. F., Fowler, B. A., Nordberg, M., \& Friberg, L. T. (2015). Handbook on the Toxicology of Metals. USA: Academic Press.

Osthoff, K. S. (2008). How Cells Die: Apoptosis and Other Cell Death Pathways (4 ed.): Roche Diagnostics.

Sari, S. R., Baehaki, A., \& Lestari, S. D. (2013). Aktivitas Antioksidan Kompleks Kitosan Monosakarida. Fishtech, 2(1), 6973.

SNI. (2009). Batas maksimum cemaran logam berat dalam pangan: Badan Standardisasi Nasional.

Suksmerri. (2008). Dampak Pencemaran Logam Timah Hitam (Pb) terhadap Kesehatan. Jurnal Kesehatan Masyarakat.

Sundari, D., Hananto, M., \& Suharjo. (2016). Kandungan Logam Berat dalam Bahan Pangan di Kawasan Industri Kilang Minyak Dumai. Buletin Penelitian Sistem Kesehatan, 19(1), 55-61. 
JURNAL INFORMASI KESEHATAN INDONESIA, VOLUME 4, NO. 2, November 2018: 80-86

Wibowo, P. A., \& Mukono, J. (2014).

Kandungan Timbal dalam Darah Pasangan

Usia Subur di Desa Tebuwung, Kecamatan

Dukun, Gresik. Jurnal Kesehatan

Lingkungan, 7(2). 